\title{
TOPICAL STEROIDS ABUSE AND IT'S HIGH PREVALENCE WITH TEANIA INFECTIONS IN COVID-19 CRISIS TIME -A CLNICO EPIDEIMIOLOGICAL STUDY
}

KEY WORDS: Steroid Abuse, teania infection Clinico epidemiological, COVID-19

\section{Dr B Omprakash*}

\section{Dr Jaya Krishna}

\section{Dr Kavitha}

Professor Dermatology, Srinivasa Medical College , Mangalore, Karnataka. *Corresponding Author

Associate professor, Oral medicine radiology, Dental dept, Nizamabad Govt. Medical College,NZB, Telangana.

Introduction: Topical corticosteroids are today among the most commonly prescribed medications indermatology clinics. Due to easy availability of steroid creams as over-the-counter drugs Steroid abuse has become a common problem. This study was conducted to see the magnitude of this problem of it and the clinical profile of these patients in our population in one part of south India.

Material And Methods: All patients with a history of topical use of steroids on different skin problems mainly teania infected areas for a period greater than few months were enrolled in this study after taking an informed consent. A detailed history about the type of steroid used, duration of application, source of prescription of the drug (doctor/chemist/self/acquaintances) and indications were recorded. A detailed clinical examination of these patients was carried out and results were recorded.

Results: This study was conducted over a period of 1 year and 380 patients who fulfilled the inclusion criteria were enrolled in this study. There were 247 males and 133 female patients. The range of age of these patients varied from 5 years to 60 years. Teania cruris was the most common indication for steroid use. Severity of problem was got neglected mainly because of covid crisis time situation and other misguidance by ignorance, friends and Chemists. Chemists were the most common source of prescribing steroids. COVID economic crisis may be an another leading factor of using the easy avilable medicine at counter for mild to moderate severity of skin problems especially fungal tinea corporis/cruris. Atrophic changes of the skin were the most common adverse effects seen.

Conclusion: Topical steroids are very commonly abused drugs. This problem is more common in youngsters, especially males. Over the counter availability of these drugs in our part of world is a major cause of their abuse

\section{INTRODUCTION:}

Steroids have been in use as topical agents for a long time now ${ }^{1}$.The use of topical steroids has been on a rise since their inception ${ }^{2}$ Topical corticosteroids are today among the most commonly prescribed medications in dermatology clinics $^{3}$ Steroid abuse is a common problem due to easy availability of steroid creams as over-the-counter drugs. ${ }^{3}$. Steroids exert various effects on the skin- anti-inflammatory, antipruritic, melanopenic, atrophogenic, and immunosuppressive. All these effects can be a cause of adverse effects of steroids from their prolonged or unwarranted use ${ }^{4}$. This study was conducted to see the magnitude of this problem of steroid abuse and the clinical profile of these patients during this covid 19 crisis time (2019-20).

\section{MATERIAL AND METHODS:}

This study was conducted in the outpatient department of dermatology of a tertiary care hospital in south India over a period of 1 year from June 2019 to May 2020, after approval from the intuitional ethics committee. All patients with a history of topical use of steroids on skin on various uses for a period greater than few month were enrolled in this study after taking an informed consent. A detailed history about the type of steroid used, duration of application, source of prescription of the drug (doctor/chemist/self/ acquaintances) and indications were recorded. A detailed clinical examination of these patients was carried out and results were recorded, especially with regard to adverse effect from steroid use. Patients with rosacea without steroid usage, patients on systemic corticosteroid therapy, patients with co-morbidities that resemble TC side-effects viz polycystic ovaries, Cushing's syndrome, thyroid disorders were excluded from the study. Laboratory investigations were done on a case to case basis as per the individual requirement.

\section{RESULTS:}

This study was conducted over a period of 1 year and 380 patients who fulfilled the inclusion criteria were enrolled in this study. There were 247 males and 133 female patients. The range of age of these patients varied from 5 years to 60 years, with a median age of 22 years (Table 1). Most of the patients $(62.2 \%)$ were from rural background. The duration of steroid use varied from 2 month to 10 years. The various clinicoepidemiologic parameters are shown in table 1 to 4 .

\section{DISCUSSION}

This study was conducted over a period of 1 year. 380 patients fulfilled the inclusion criteria and were included in the study. The misuse/overuse of topical steroids is very rampant ${ }^{3}$ and this may be a fraction of the actual number of cases of steroid misuse. males formed the major chunk $(81.6 \%)$ of the study group. This is likely because of apply some medication to their itchy black effected areas in their busy working schedule, poverty and ignorance especially in this covid crisis depressed period.

The most common use of topical steroids easy available immediate relief property ant-itchy skin lightening property adds poor patients were more likely to use these preparations. Our study is differing from Sheikh Manzoor et al

whose study focused on face vs topical use revealed commonest as cosmetic abuse that to in female patients mainly on face and it was non covid time where as our study revealed commonest use for Itchy inner parts(groin) more common that to in males. A sheikh manzoor et al trend was seen in earlier studies. ${ }^{3,5,6}$ Most of the patients in our study $(62.2 \%)$ were from rural background. Our results differ from those of other researchers like Saraswat et $\mathrm{al}^{7}$, who found this problem more prevalent in urban areas. The reasons for higher prevalence in rural areas could be less access to qualified dermatologists in these areas and easy dispensing of these drugs by chemists in rural areas without asking for any prescriptions. Most of the patients who had adverse effects from steroid abuse were in the age group of 21-30 years. This is the stage in lives of youngsters might use some 
medications just based on advice of friends or relatives to take care of some major or minor skin problems.

Infact we found in our study that the most common indication for using topical steroids was as anti itchy cream. Where as Various studies ${ }^{5}$ have shown that common people perceive topical steroids as anti-itchy whitening creams and this problem is more common in countries where coloured people live, as in Asia. This problem is aggravated by the easy availability of steroid preparation at the chemist shops, where these are dispensed without a prescription in the third world countries. ${ }^{89}$ An alarming trend seen by us was that the maximum number of our patients $(58.3 \%)$ were using potent steroids and a good number of patients $(20 \%)$ were using very potent steroids. This indicates that the steroid use was not based on prescription from a qualified dermatologists. This also makes up for increased chances of adverse effects from topical steroid use. earlier studies by Yasmeen et $\mathrm{al}^{2}$ and Dey et $\mathrm{al}^{3}$ also showed that potent and very potent steroids were the ones most commonly used by patients.

The patients don't have idea about the potency and resulting adverse effect profile of these drugs. Chemists/drug stores were the most common source $(62.7 \%)$ of steroid prescription/ advice in our cases. Though there are legislations in place to prevent sale of drugs without prescription of a registered medical practitioner, the ground level implementation of these legislations remains elusive. Various types of adverse effects were noted in these patients. Rebound flare/ erythema, atrophic changes like telengiectasias, steroid atrophy and easy bruising were the most common adverse effects seen. Ammar F. Hameed ${ }^{10}$ and Yasmeen et $\mathrm{al}^{2}$ have recorded similar observations. Others included hirsutism / hyper trichosis, steroid acne, xerosis, hypo or hyper pigmentation. There is very little awareness among the masses about adverse effects of steroids. The steroids have initial good response on skin due to their antiinflammatory/ bleaching actions and it leads to an ignorant layman becoming accustomed to using steroids regularly. Subsequently the adverse effects of steroids become apparent.

\section{CONCLUSION:}

Topical steroids are very commonly abused drugs mainly in teania affected areas. More chronic sever cases noted in this covid crisis time. This problem is more common in youngsters, especially males. Over the counter availability of these drugs in our part of world is a major cause of their abuse. To tackle this problem, a multi-pronged approach is needed in form of education of masses, effective implementation of legislation to stop dispensing of drugs without proper prescription and sensitization of pharmacists/chemists towards this issue.

Table-1: Age Distribution Of Patients Using Topical Corticosteroids For Skin Problems

\begin{tabular}{|l|l|}
\hline Age distribution & Number of patients \\
\hline $1-10$ & 12 \\
\hline $11-20$ & 31 \\
\hline $21-30$ & 203 \\
\hline $31-40$ & 89 \\
\hline $41-50$ & 31 \\
\hline $51-60$ & 14 \\
\hline
\end{tabular}

Table-2: Indications of topical steroid use and source of prescription

\begin{tabular}{|l|l|l|l|}
\hline Indication & $\begin{array}{l}\text { Number } \\
\text { of } \\
\text { patients }\end{array}$ & $\begin{array}{l}\text { Source of drug } \\
\text { prescription/ad } \\
\text { vice }\end{array}$ & $\begin{array}{l}\text { Number of } \\
\text { patients }\end{array}$ \\
\hline Tinea & 152 & $\begin{array}{l}\text { Chemist/ Drug } \\
\text { stores }\end{array}$ & 213 \\
\hline $\begin{array}{l}\text { Melasma and hyper } \\
\text { pigmentation }\end{array}$ & 78 & $\begin{array}{l}\text { Acquaintances/ } \\
\text { Relatives/Self }\end{array}$ & 143 \\
\hline
\end{tabular}

\begin{tabular}{|c|c|c|c|}
\hline Acne & 43 & paramedics & 16 \\
\hline $\begin{array}{l}\text { Predominantly with } \\
\text { Oral conditions } \\
\text { lichen planus, sub } \\
\text { mucus fibrosis, } \\
\text { Allergic dermatitis } \\
\text { stomatitis, recurrent } \\
\text { opthus ulcer } \\
\text { erythema } \\
\text { multiforme minor } \\
\text { etc }\end{array}$ & 27 & $\begin{array}{l}\text { General } \\
\text { practitioners } \\
\text { (Non- } \\
\text { dermatologists) }\end{array}$ & 05 \\
\hline $\begin{array}{l}\text { Skin softening daily } \\
\text { use cream }\end{array}$ & 31 & Dermatologists & 03 \\
\hline photo dermatitis & 9 & & \\
\hline Irritant dermatitis & 12 & & \\
\hline $\begin{array}{l}\text { Lichen planus, } \\
\text { psoriasis ( skin and } \\
\text { oral) }\end{array}$ & 21 & & \\
\hline Vitiligo & 7 & & \\
\hline
\end{tabular}

Table-3: Potencies Of Various Topical Steroids Used By Patients.

\begin{tabular}{|c|c|c|}
\hline \begin{tabular}{|l|}
$\begin{array}{l}\text { Potency of steroid } \\
\text { preparation }\end{array}$ \\
\end{tabular} & Name of drug & $\begin{array}{l}\text { Number of } \\
\text { Patients }\end{array}$ \\
\hline \multirow[t]{2}{*}{\begin{tabular}{|l|} 
Very potent \\
steroids
\end{tabular}} & $\begin{array}{l}\text { Clobetasol } \\
\text { propionate with } \\
\text { salicylic acid }\end{array}$ & 18 \\
\hline & $\begin{array}{l}\text { Clobetasol } \\
\text { propionate } 0.05 \%\end{array}$ & 54 \\
\hline \multirow[t]{3}{*}{ Potent steroids } & \begin{tabular}{|l|} 
Betamethasone \\
valerate $0.1 \%$
\end{tabular} & 162 \\
\hline & $\begin{array}{l}\text { Mometasone } \\
\text { furoate } 0.1 \% \\
\end{array}$ & 18 \\
\hline & $\begin{array}{l}\text { Fluticasone } \\
\text { propionate } 0.05 \%\end{array}$ & 30 \\
\hline \begin{tabular}{|l|}
$\begin{array}{l}\text { Moderately potent } \\
\text { steroids }\end{array}$ \\
\end{tabular} & Clobetasone & 12 \\
\hline \begin{tabular}{|l|}
$\begin{array}{l}\text { Mildly potent } \\
\text { steroids }\end{array}$ \\
\end{tabular} & Hydrocortisone & 06 \\
\hline Mixed & $\begin{array}{l}\text { Combination of } \\
\text { steroid with } \\
\text { hydroquinone, } \\
\text { antibacterial and } \\
\text { antifungal } \\
\end{array}$ & 80 \\
\hline
\end{tabular}

Table-4: Adverse Effects Of Steroids

\begin{tabular}{|l|l|l|}
\hline Atrophic changes & Steroid atrophy & 90 \\
\hline & Telangiectasia & 79 \\
\hline & Easy bruising & 08 \\
\hline Infections & Tinea incognito & 09 \\
\hline Miscellaneous & Steroid acne & 45 \\
\hline & Per oral dermatitis & 15 \\
\hline & Hirsutism/hypertrichosis & 47 \\
\hline & Hyperpigmentation & 19 \\
\hline & Hypopigmentation & 09 \\
\hline & Photosensitization & 07 \\
\hline & Rebound flare/Erythema & 80 \\
\hline & Xerosis & 50 \\
\hline & Steroid Rosacea & 19 \\
\hline
\end{tabular}

\section{REFERENCES}

1. Ljubojeviae S, Basta JA, Lipozeneiae J. Steroid dermatitis resembling rosacea: aetiopathogenesis and treatment.JEur Acad DermatolVenerol.2002;16:121-6.

2. Yasmeen J Bhat, Sheikh Manzoor, Seema Qayoom. Steroid-induced rosacea: a clinical study of 200 patients.Indian Journal of Dermatology. 2011;56(1)

3. Vivek Kumar Dey. Misuse of topical corticosteroids: A clinical study of adverse effects. Indian Dermatology. 2014;5.

4. Hengge UR, Ruzicka T, Schwartz RA, Cork MJ. Adverse effects of topical glucocorticosteroids.J Am Acad Dermatol. 2006;54:1-15.

5. Mahé A, Blanc L, Halna JM, Kéita S, Sanogo T, Bobin P. An epidemiologic survey on the cosmetic use of bleaching agents by the women of Bamako (Mali). Ann DermatolVenereol. 1993;120:870-3.

6. Arnold J, Anthonioz P, Marchand JP. Depigmenting action of corticosteroids. Experimental study on guinea pigs. Dermatologica. 1975;151:274-80.

7. Saraswat A, Lahiri K, Chatterjee M, Barua S, Coondoo A, Mittal A, et al. Topical corticosteroid abuse on the face: A prospective, multicenter study of dermatology outpatients. 
8. Indian J Dermatol Venereol Leprol. 2011;77:160-6. 8. Al-Dhalimi MA, Aljawahiri N. Misuse of topical corticosteroids: A clinical study from an Iraqi hospital.East Mediterr Health J.2006;12:847-52.

9. Solomon BA, Glass AT, Rabbin PE. Tinea incognito and "overthe- counter" potent topical steroids. Cutis. 1996;58:295-6.

10. Ammar F. Hameed. Steroid Dermatitis Resembling Rosacea: A Clinical Evaluation of 75 Patients. ISRN Dermatology Volume 2013, Article ID 491376.

11. Sheikh Manzoor 1, Syed Shahab ud din Bukhari2, Suhail Rahim Rather2, Samia Aleem2, Mohamad Rafiq2,Mohmad Iqbal Rather3 Volume 4 | Issue 7 | July 2017 | ICV (2015): 77.83 |Topical Steroid Abuse: Clinicoepidemiological Profile International Journal of Contemporary Medical Research 